\title{
RESEARCH
}

Open Access

\section{Assessing above-ground biomass-functional diversity relationships in temperate forests in northern Mexico}

Benedicto Vargas-Larreta1, Jorge Omar López-Martínez ${ }^{2,3 *}$ D, Edgar J. González ${ }^{4}$, José Javier Corral-Rivas ${ }^{5}$ and Francisco Javier Hernández ${ }^{1}$

\begin{abstract}
Background: Studies on the relationship between biodiversity and ecosystem productivity have suggested that species richness and functional diversity are the main drivers of ecosystem processes. Several patterns on this relationship have been found, including positive, unimodal, negative, and neutral trends, keeping the issue controversial. In this study, taxonomic diversity and functional diversity as drivers of above-ground biomass (AGB) were compared, and the mechanisms that influence biomass production were investigated by testing the complementarity and the mass-ratio hypotheses.
\end{abstract}

Methods: Using data from 414 permanent sample plots, covering 23\% of temperate forest in the Sierra Madre Oriental (México), we estimated the above-gound biomass (AGB), taxonomic and functional diversity indices, as well as community weighted mean values (CWM) for three functional traits (maximum height, leaf size and wood density) for trees $\geq 7.5 \mathrm{~cm} \mathrm{DBH}$, in managed and unmanaged stands. To compare taxonomic diversity differences between managed and unmanaged stands we carried out a rarefaction analysis. Furthermore, we evaluated the relationship between $A G B$ and taxonomic and functional diversity metrics, as well as CWM traits throught spatial autoregressive models.

Results: We found a hump-shaped relationship between AGB and species richness in managed and unmanaged forests. CMW of maximum height was the most important predictor of AGB in both stands, which suggested that the mechanism underlaying the AGB-diversity relationship is the dominance of some highly productive species, supporting the mass-ratio hypothesis. Above-ground biomass was significantly correlated with three of the five functional diversity metrics, CWM maximum height and species richness. Our results show the importance of taking into account spatial autocorrelation in the construction of predictive models to avoid spurious patterns in the AGBdiversity relationship.

\footnotetext{
* Correspondence: Imjorgeomar@gmail.com

${ }^{2}$ Cátedras, CONACYT, 1582, Av. Insurgentes Sur, Ciudad de México, Mexico

${ }^{3}$ El Colegio de la Frontera Sur, 77014, Chetumal, Quintana Roo, Mexico

Full list of author information is available at the end of the article
}

\section{Springer Open}

(c) The Author(s). 2021 Open Access This article is licensed under a Creative Commons Attribution 4.0 International License, which permits use, sharing, adaptation, distribution and reproduction in any medium or format, as long as you give appropriate credit to the original author(s) and the source, provide a link to the Creative Commons licence, and indicate if changes were made. The images or other third party material in this article are included in the article's Creative Commons licence, unless indicated otherwise in a credit line to the material. If material is not included in the article's Creative Commons licence and your intended use is not permitted by statutory regulation or exceeds the permitted use, you will need to obtain permission directly from the copyright holder. To view a copy of this licence, visit http://creativecommons.org/licenses/by/4.0/. 


\begin{abstract}
(Continued from previous page)
Conclusion: Species richness, maximum height, functional richness, functional dispersion and RaoQ indices relate with above-ground biomass production in temperate mixed-species and uneven-aged forests of northern Mexico. These forests show a hump-shaped AGB-species richness relationship. Functional diversity explains better AGB production than classical taxonomic diversity. Community weighted mean traits provide key information to explain stand biomass in these forests, where maximum tree height seems to be a more suitable trait for understanding the biomass accumulation process in these ecosystems. Although the impact of forest management on biodiversity is still debated, it has not changed the AGB-diversity relationships in the forests of the Sierra Madre Occidental, Mexico.
\end{abstract}

Keywords: Taxonomic diversity, Functional diversity, Complementarity hypothesis, Mass-ratio hypothesis

\section{Background}

One of the most important topics in community ecology has been understanding the mechanisms that underlie ecosystem processes. Particularly, the aboveground biomass (AGB)-biodiversity relationship has been extensively studied in different ecosystems with controversial conclusions. For example, some studies developed across the world with forest inventory data, suggest a positive relationship between $A G B$ and species diversity (Gamfeld et al. 2013; Forrester and Bauhus 2016); however, negative (Reich et al. 2004), unimodal (Wang et al. 2012) and null relationships (Grace et al. 2016) have also been reported.

Two hypotheses have been widely postulated to understand the effects of biodiversity on ecosystem processes, the complementarity hyphotesis proposed by Tilman (1997) and the mass-ratio hypothesis by Grime (1998). The complementarity hyphotesis proposes that species richness and functional diversity, as well as the difference in functional traits between species, maximize the variety of resource use strategies, and that less overlap of niches along the resource axes increases the functioning of the ecosystem through the partition of the niche. In natural ecosystems, it has been suggested that at very low levels of productivity, species richness is limited, and only a few species are adapted to survive under nutrientpoor conditions. Conversely, at high levels of productivity, competition for light and space leads to competitive exclusion of species, with only a few been dominants. On the other hand, Grime (1998) postulated that the productivity of a community is determined by the relative abundance of the functional traits values of the dominant contributors to the plant biomass. According to this hypothesis, ecosystem properties such as biomass should be predictable from the weighted mean community values (CWM) of traits with links to the capture, use, and release of resources at the individual and ecosystem levels (Díaz et al. 2007). Likewise, the assumptions of Grime's hypothesis consider that functional aspects of the dominant species have a greater influence on ecosystem processes because few highly competitive species increase interspecific competition and, eventually, decrease complementary processes and, in consequence, decrease functional diversity. However, this relationship and their underlying mechanisms are still debated (Kirby and Potvin 2007; Schumacher and Roscher 2009; Schuldt et al. 2014; Isbell et al. 2015; Zhang and Chen 2015; Cheng et al. 2018).

One of the main approaches for understanding the relationship between species diversity and ecosystem productivity has been through species richness (Díaz and Cabido 2001). Although species richness might provide a reasonable measure, many of the processes that regulate the functioning of ecosystems are difficult to assign to each species, and it is not possible to determine their relative contributions to ecosystem functioning and productivity. Accordingly, species richness assumes that all species are equivalent and does not consider functional differences among species (i.e. functional diversity), key determinants of ecosystem functioning (Tilman 2001).

The importance of functional diversity (FD) in explaining AGB production has recently been recognized and debated (Tilman et al. 1997; Conti and Díaz 2013; Becknell and Powers 2014). Functional diversity is a component of biodiversity that encompasses the characteristics of species and predicts more accurately the functioning of the ecosystem (Petchey and Gaston 2002; Hooper et al. 2005; Cianciaruso et al. 2009). Moreover, FD links morphological, physiological and phenological variation at the individual level with ecosystem processes and patterns (Petchey et al. 2009). Functional diversity metrics are based on traits, which are correlated with environmental filters. In relation to the functioning of organisms, the traits modulate their suitability, allow understanding the interactions between organisms and the components of their environment, and link the different levels of organization of ecological systems (McGill et al. 2006; Violle et al. 2007).

Some authors have proposed that functional diversity and functional traits may be more reliable predictors of ecosystem productivity than taxonomic diversity, which 
represents species-based diversity indices (including species richness, Shannon and Simpson diversity indices), as plant functional traits are often used as proxies to determine whether species have different ecological strategies for resource acquisition (Vitousek and Hooper 1993; Lawton and Brown 1994; Cornelissen et al. 2003; McGill et al. 2006). However, despite efforts to link functional diversity of plant communities to productivity, the relationships are still not entirely clear.

Most of the studies on this topic have been carried out in relatively simple ecosystems, such as grasslands and monocultures; however, no records have been found in "natural" forest ecosystems with a long history of management as the uneven-aged and multispecies temperate forests of Durango, Mexico. The forests of Durango are the most important forests in Mexico because of their extent and economical value. These forests are of particular interest, not only because they represent a unique ecosystem (with 20 pine and 43 oak species and some species of the genera Arbutus, Fraxinus, Cupressus, Juniperus and occasionally Abies and Pseudotsuga) (González-Elizondo et al. 2012), but also because they are owned and managed by local communities in the form of collective land ownerships known as "Ejidos", or indigenous land holdings known as "Comunidades" (Madrid et al. 2009). Most of the forests in Durango are uneven-aged, and conifer species occur as mixtures with broadleaf species. This irregularity refers to the spatial arrangement of trees (vertical and horizontal irregularity) and the variation in the age structure of trees and stands. The management of these mixed uneven-aged forests is more complex than the management of even-aged forests, and one of the most pressing research problems is the development of models to define sustainable harvests. In that sense, no study has attempted to evaluate the effect of tree species diversity on forest productivity.

In this study, we address two topics widely debated in the current literature. On the one hand, we test the predictive power of taxonomic and functional diversity on above-ground biomass prediction in a managed forest landscape. On the other hand, based on the calculation of the taxonomic and functional diversity metrics in managed and unmanaged forests, we evaluate the effect of the complementarity and the mass-ratio hypotheses. In particular, we tested if functional diversity metrics will be better predictors of forest biomass, and whether, since forests are managed under a wood-oriented forestry model, the dominant species will play a predominant role in the AGB-diversity relationship of the ecosystem (mass-ratio hypothesis).

\section{Materials and methods}

\section{Study area and inventory data}

The study was conducted in the temperate forests of Durango, Mexico $\left(22^{\circ} 20^{\prime} 49^{\prime \prime}\right.$ to $26^{\circ} 46^{\prime} 33^{\prime \prime} \mathrm{N}$; $103^{\circ} 46^{\prime}$ $38^{\prime \prime}$ to $\left.107^{\circ} 11^{\prime} 36^{\prime \prime} \mathrm{W}\right)$, which occupies about $23 \%$ of the Sierra Madre Occidental mountain range (Fig. 1). The elevation above sea level varies between 1200 and 3200 $\mathrm{m}$ (average $2264 \mathrm{~m}$ ). Precipitation ranges from 443 to $1452 \mathrm{~mm}$, with an anual average of $917 \mathrm{~mm}$, whereas the mean annual temperature varies from 8.2 to $26.2^{\circ} \mathrm{C}$, with an anual average of $13.3^{\circ} \mathrm{C}$ (Silva-Flores et al. 2014). Dominat vegetation types are pine-oak forests. Some major tree groups occur in these forests, with important tree families including Pinaceae, Fagaceae, and Betulaceae; dominant shrub families include Rosaceae and Ericaceae.

Durango is the most important forestry state in Mexico, with 4.9 million ha of natural forests (mostly managed) and an average timber production of 1.8 million $\mathrm{m}^{3}$ in the last decade $(29.7 \%$ of the national forest production) (SEMARNAT 2016). These forests are shaped by more than one century of timber-oriented forestry, mainly by selective removals for sustainable timber production, but also for the maintenance of biological diversity and uneven-aged stand structures (Padilla-Martínez et al. 2020).

The data were obtained from 414 permanent sample plots (PSP) used to monitor the growth and yield of Durango's forests (Crecente-Campo et al. 2014), of which 365 are placed in managed stands and 49 in unmanaged stands. The plots were mostly measured between 2011 and 2015, and cover the main forest types and the current diameter distributions of commercial forests in Durango. The plots are $50 \mathrm{~m} \times 50 \mathrm{~m}$ in size and were distributed by systematic sampling, with a variable grid ranging from 3 to $5 \mathrm{~km}$. The following variables by species were recorded: diameter at breast height (DBH, measured in $\mathrm{cm}$ at $1.3 \mathrm{~m}$ above ground level), total tree height $(\mathrm{m})$, height to the live crown $(\mathrm{m})$, azimuth $\left(^{\circ}\right.$ ) and radius (m) from the centre of the plot to all trees equal or larger than $7.5 \mathrm{~cm}$ on diameter at breast height. The following stand variables were calculated from the tree data recorded in each plot: stems per hectare $(\mathrm{N})$, stand basal area $\left(\mathrm{G}, \mathrm{m}^{2} \cdot \mathrm{ha}^{-1}\right)$, quadratic mean diameter $(\mathrm{dg}, \mathrm{cm})$, and dominant height $(\mathrm{H} 0, \mathrm{~m})$. Dominant height was calculated from the proportion of the 100 pine trees with the largest diameter per hectare. The PSP represent two broad conditions based on management history and structural attributes: (1) unmanaged stands (more than 50 years of non-management history); and (2) managed stands, with components of structural heterogeneity in form of multi-layered canopy.

A total of 67,991 trees were recorded, comprising 63 plant species belonging to 14 genera and 9 families. The dominant families were Fagaceae (26 species), Pinaceae (15 species), and Cupressaceae (eight species). The most abundant species were Pinus durangensis (14,683 stems), Quercus sideroxila (7891), P. arizonica (7281), P. cooperi 


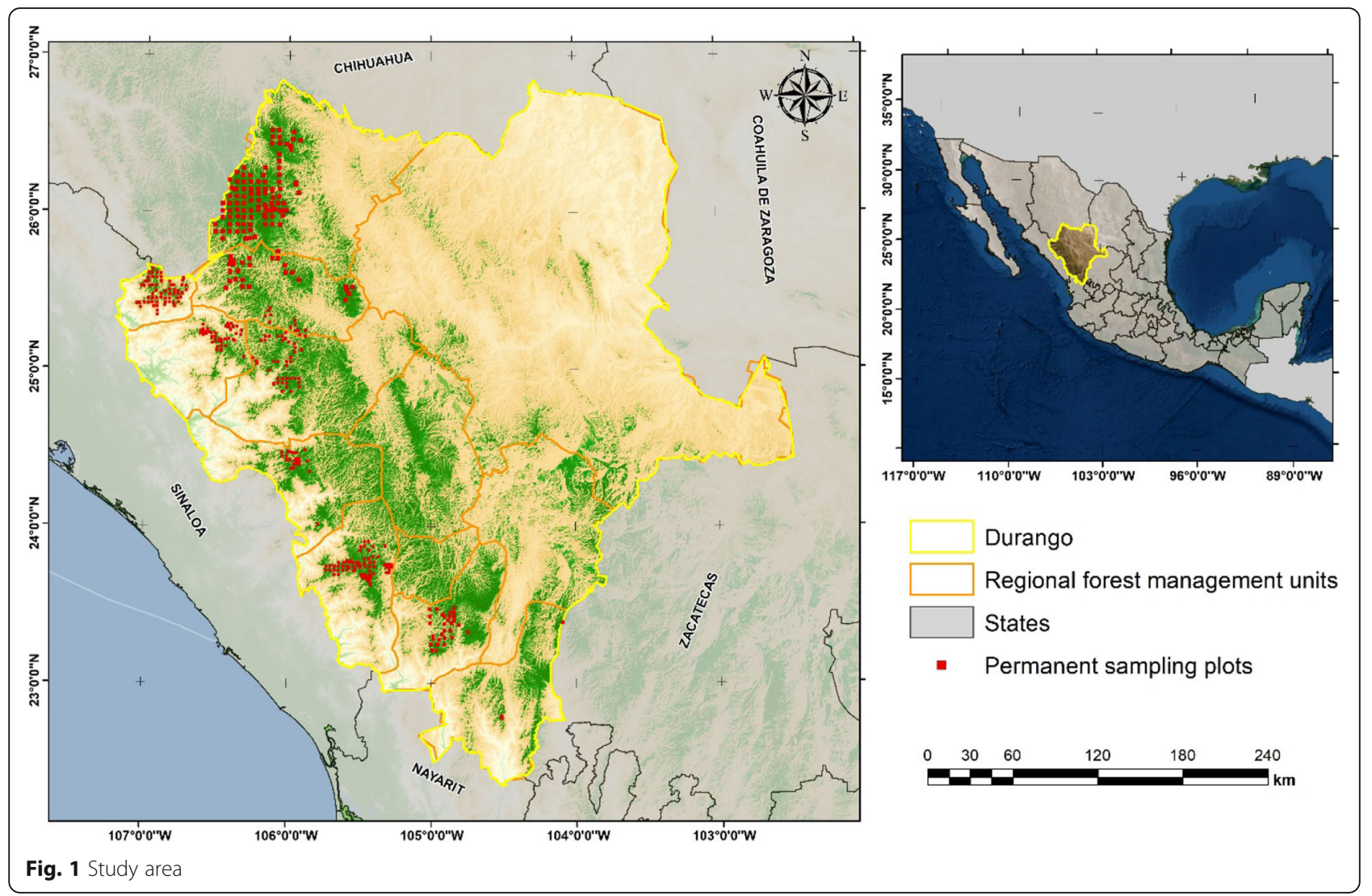

(5309), P. teocote (4354), P. strobiformis (3082), P. leiophylla (2696), Q. crassifolia (2675), P. herrerae (2215) and Juniperus deppeana (2001). Tree number per plot ranged from 64 to 466 stems, with an average value of 158 stems per plot.

\section{Biomass estimates}

Above-ground biomass (AGB) was considered as measure of stand productivity. AGB of live trees in each plot was estimated using species-specific allometric equations based on DBH and total height (h) developed specifically for all major Durango coniferous and broadleaf tree species (Vargas-Larreta et al. 2017). We used the biomass equations reported by Rojas-García et al. (2015) for less frequently occurring species, or for those tree species for which no biomass equations were developed in the study carried out by Vargas-Larreta et al. (2017).

\section{Functional traits}

We measured three functional traits for the species present in each individual plot: maximum tree height (Hmax, $\mathrm{m}$ ), wood density (WD, g.cm $\mathrm{cm}^{-3}$ ), and leaf size (LS, cm). Functional traits Hmax and WD are the most important and commonly studied traits, and are accurate predictors of stand biomass (Ruiz-Benito et al. 2014; Wu et al. 2015). Moreover, we selected these traits because they are important drivers of plant growth and survival (Poorter et al. 2008; Wright et al. 2010; Rüger et al. 2012), and hence for standing above-ground biomass, biomass productivity and carbon stocks (Pérez-Harguindeguy et al. 2013). Tree height was measured in the field, whereas the data for wood density were extracted from the literature for the major tree species in Mexico (Ordoñez Díaz et al. 2015). LS values were compiled from Farjon and Filer (2013) and García and González (2003).

\section{Taxonomic diversity and functional diversity}

Taxonomic diversity, which includes species richness (number of species per plot; $S$ ) and species diversity (Shannon-Weener index; $H^{\prime}$, and Simpson's index; $\lambda$ ), community-weighted mean (CWM) traits, as well as functional-based diversity indices (functional diversity), were used as diversity metrics. For each plot, we calculated the taxonomic diversity metrics, the CWM traits CWM_Hmax, CWM_LS, and CWM_WD, and the following functional diversity indices: functional richness (FRic), functional evenness (FEve), functional divergence (FDiv), functional dispersion (FDis), and Rao's quadratic entropy index (RaoQ) (Rao 1982; Mason et al. 2005; Villéger et al. 2008; Laliberté and Legendre 2010).

The CWM represents the most probable attribute that an individual would have if drawn at random from the 
community. The CWM of a single trait was calculated as the averaged trait value in the community, weighted by the abundance of the species (Garnier et al. 2004). Rao's index (RaoQ) is one of the most common indices of funtional diversity, and estimates the abundanceweighted variance of the dissimilarities between all species pairs (Leps et al. 2006).

As proposed by Mason et al. (2005) and by Villéger et al. (2008), FRic represents the amount of functional space filled by the community, and it was measured using the convex hull volume method (Cornwell et al. 2006). FEve was measured using a minimum spanning tree which links all the species in the multidimensional functional space (Villéger et al. 2008). Functional dispersion (FDis) was calculated as the weighted distancies from a weighted centroid in multitrait space using plotspecific trait values (Laliberté and Legendre 2010); and functional divergence index (FDiv), was defined as the variance in the attribute values of the species present at a site, and represents the variation in trait values, weighted by the abundance of each species in the community (Mason et al. 2003). FDiv has no units, and its value ranges between 0 and 1 , were $0=$ low or no trait diversity, and $1=$ high trait diversity. The formula for CWM traits and for all the functional diversity indices described are presented in Table 1.
Functional diversity metrics (FDis, FRic, FEve, FDiv, and RaoQ) and CWM traits (CWM_Hmax, CWM_LS, and CWM_WD) were calculated by using the 'dbFD' function of Laliberté and Legendre (2010) of the FD package in $\mathrm{R}$ ( $\mathrm{R}$ Core Team 2020). The taxonomic diversity indices (Shannon-Wiener index; $\mathrm{H}^{\prime}$, and Simpson's index; $\lambda$ ) were calculated for each plot with the 'vegan' package in $\mathrm{R}$ ( $\mathrm{R}$ Core Team 2020).

\section{Statistical analyses}

To compare observed species richness of woody plants between managed and unmanaged stands, we carried out a rarefaction approach using iNEXT (Colwell et al. 2012; Chao et al. 2014; Hsieh et al. 2016) on individualbased rarefaction for a comparable number of individuals (6926). To carry out rarefaction analysis we use the minimum sample size approach.

As the visual inspection of AGB plotted against taxonomic diversity and functional diversity measures clearly indicated unimodal relationships, we fitted quadratic models to assess how stand biomass related to diversity $\left(S, H^{\prime}, \lambda\right)$, mean trait values $(C W M)$ and functional diversity of the stands. Due to the presence of spatial autocorrelation among biomass data (Moran's $I=0.151, p<0.0001)$, we considered both regression and generalized least squares (GLS) models (Dormann

Table 1 CWM and functional diversity indices used to describe the functional structure of the forests evaluated

\begin{tabular}{|c|c|c|}
\hline Index & Expression & Description \\
\hline CWM & $\mathrm{CWM}_{x}=\sum p_{i} x_{i}$ & $\begin{array}{l}\text { CWMx is the CWM for the trait } x, p_{i} \text { is the relative abundance of } \\
\text { species } i \text { in the community, and } x_{i} \text { is the trait value for the species } i \text {. }\end{array}$ \\
\hline RaoQ & RaoQ $=\sum_{i=1}^{S} \sum_{j=1}^{S} d_{i j} p_{i} p_{j}$ & $\begin{array}{l}p_{i} \text { and } p_{j} \text { are the relative abundances of species } i \text { and } j \text {, and the } d_{i j} \\
\text { values are the dissimilarities between species } i \text { and } j \text { in the } \\
\text { community. }\end{array}$ \\
\hline FRic & $\left(K x_{a_{1}}+(1-K) x_{b_{1}}, K x_{a_{2}}+(1-K) x_{b_{2}}, \ldots, K x_{a_{T}}+(1-K) x_{b_{T}}\right)$ for $0 \leq K \leq 1$ & $\begin{array}{l}a \text { and } b \text { are species inside the convex hull volume, whose } \\
\text { coordinates, i.e., trait values, are }\left(x_{a 1}, x_{a 2}, \ldots, x_{a T}\right) \text { and }\left(x_{b 1}, x_{b 2}, \ldots, x_{b T}\right) \text {, } \\
\text { respectively. }\end{array}$ \\
\hline FEve & $\begin{array}{l}\text { FEev }=\frac{\sum_{l=1}^{S-1} \min \left(\mathrm{PEW}_{l}, \frac{1}{S-1}\right)-\frac{1}{S-1}}{1-\frac{1}{S-1}} \\
\text { with } \\
\mathrm{PEW}_{l}=\frac{\mathrm{EW}_{l}}{\sum_{l=1}^{S-1} \mathrm{EW}_{l}} \\
\text { and } \\
\mathrm{EW}_{l}=\frac{\text { dist }(i, j)}{W_{i}+W_{j}}\end{array}$ & $\begin{array}{l}\text { EW is weighted evenness; dist }(i, j) \text { is the Euclidean distance between } \\
\text { species } i \text { and } j \text {, the species involved is branch } I \text {, and } w_{i} \text { is the relative } \\
\text { abundance of species } i \text {. PEW is the partial weighted evenness; } S \text { is } \\
\text { number of species. }\end{array}$ \\
\hline FDis & $\begin{array}{l}\text { FDis }=\frac{\sum a_{j} z_{j}}{\sum a_{j}} \\
\text { and } \\
\mathbf{c}=\left[c_{i}\right]=\frac{\sum a_{j} x_{j}}{\sum a_{j}}\end{array}$ & $\begin{array}{l}a_{j} \text { is the abundance of species } j \text { and } z_{j} \text { is the distance of species } j \text { to } \\
\text { the weighted centroid } \mathbf{c} \text {, where } \mathbf{c} \text { is the weighted centroid in the } i \text { - } \\
\text { dimensional space, and } x_{i j} \text { the attribute of species } j \text { for trait } i \text {. }\end{array}$ \\
\hline FDiv & $\begin{array}{l}\text { FDiv }=\frac{2}{\pi} \arctan (5 V) \\
\text { with } \\
V=\sum p_{i}\left(\ln x_{i}-\ln x\right)^{2} \\
\text { and } \\
p_{i}=\sum a_{i} \\
\sum a_{i}\end{array}$ & $\begin{array}{l}5 \text { is a scaling factor used to define the index over a range of } 0-1 \text {, } \\
\text { and } V \text { is the weighted variance of trait } x \text {. In } x_{i} \text { is the trait value for the } \\
\text { species } i ; a_{i} \text { is the relative abundance of species } i \text { in the community. }\end{array}$ \\
\hline
\end{tabular}


et al. 2007). For the latter, we included a Gaussian correlation structure based on the distance between plots. Confidence intervals were calculated using bootstrap resampling and goodness-of-fit was assessed through Pearson's $R^{2}$ for the regression model, and the squared correlation measure $r^{2}$ in the GLS case (Smith 2020). All analyses were performed in R (R Core Team 2020) using package nlme (Pinheiro et al. 2020).

\section{Results}

Minimum, maximum and mean values of diversity metrics and functional diversity indices, as well as of AGB for the analysed plots are summarized in Table 2.

Species richness was greater in managed stands than in unmanaged ones (average 7.5 and 6.78, respectively); as well as the mean values of Shannon-Wiener $\left(H^{\prime}\right)$ and Simpson $(\lambda)$ indices (Table 2). In the same sense, the rarefaction analysis showed significant differences in species richness estimations between managed (53.22, CI: 52.7-54.47) and unmanaged stands (46.81, CI: 44.9448.69). Meanwhile, the CWM mean values of Hmax, LS and WD were higher in managed stands than in unmanaged stands; the same case was for all functional diversity measures (Table 2). Unmanaged stands accumulated 16.9\% less AGB than managed stands (Table 2); the minimun AGB value (12.24 Mg.ha ${ }^{-1}$ ) was found in the unmanaged stands, whereas the maximum AGB value

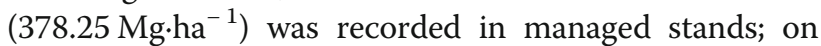
average, managed stands had more biomass than unmanaged stands (average 137.8 and $114.42 \mathrm{Mg} \mathrm{ha}^{-1}$, respectively).

\section{AGB - taxonomic diversity relationship}

Above-ground biomass values varied considerably with species richness $(S)$, and a significant relationship between AGB and number of species was found for all plots together (Table 3). It was observed a slight trend for the entire data set, through a smooth unimodal curve of AGB respect to species richness (Fig. 2). The relationship was quadratic (2nd order polynomial regression: $R^{2}=0.04, p<0.0001 ;$ Table 3$)$. Furthermore, the 2nd order GLS model allowed confirming that AGB was linked to a nonlinear relationship with species richness, showing in both cases the well-known hump-shaped trend between biomass and diversity; i.e., AGB was highest at medium species richness values and then decreased with the stand number of species (Fig. 2). Average AGB among species richness values ranged from 69.6 to $160.6 \mathrm{Mg} \cdot \mathrm{ha}^{-1}$, with the highest AGB mean values associated with values from 7 to 9 species per plot.

Above-ground biomass was unrelated to Shannon $\left(H^{\prime}\right)$ and Simpson's $(\lambda)$ indices (figures not shown); in fact, stand biomass was not affected by any of these two taxonomic diversity indices when all plots were pooled together. AGB variability increased with the Shannon's index value and were higher at medium $H^{\prime}$ values (1.3-

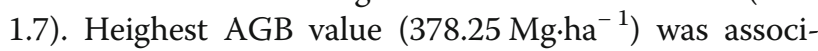
ated with a Simpson's value of 0.75 .

\section{AGB - functional diversity relationships}

The second order GLS model showed that functional diversity metrics outperform traditional taxonomic diversity indices $\left(S, H^{\prime}, \lambda\right)$, but not CWM traits, to explain the variation of AGB. AGB was significantly

Table 2 Minimum, maximum and mean values of taxonomic diversity metrics and functional diversity measures, as well as of AGB for the analysed plots

\begin{tabular}{|c|c|c|c|c|c|c|c|c|c|}
\hline \multirow[t]{2}{*}{ Measure } & \multicolumn{3}{|c|}{ All plots (414) } & \multicolumn{3}{|c|}{ Managed stands (365) } & \multicolumn{3}{|c|}{ Unmanaged stands (49) } \\
\hline & Min & Max & Mean & Min & Max & Mean & Min & Max & Mean \\
\hline Species richness $(S)$ & 2 & 14 & $7.0 \pm 2.1$ & 3 & 14 & $7.5 \pm 2.1$ & 2 & 12 & $6.78 \pm 2.34$ \\
\hline Shannon $\left(H^{\prime}\right)$ & 0.02 & 2.21 & $1.39 \pm 0.4$ & 0.1 & 2.19 & $1.4 \pm 0.41$ & 0.22 & 2.21 & $1.32 \pm 0.46$ \\
\hline Simpson $(\lambda)$ & 0.03 & 0.88 & $0.66 \pm 0.2$ & 0.03 & 0.87 & $0.66 \pm 0.17$ & 0.09 & 0.88 & $0.63 \pm 0.19$ \\
\hline CWM_Hmax & 16.67 & 46.1 & $36.98 \pm 4.4$ & 16.7 & 46.1 & $37.1 \pm 4.29$ & 12.24 & 38.28 & $28.45 \pm 5.87$ \\
\hline CWM_LS & 1.49 & 25.22 & $12.84 \pm 4.1$ & 3.9 & 24.5 & $13.1 \pm 3.93$ & 1.49 & 25.22 & $10.73 \pm 4.84$ \\
\hline CWM_WD & 0.37 & 0.63 & $0.47 \pm 0.05$ & 0.37 & 0.63 & $0.47 \pm 0.05$ & 0.38 & 0.61 & $0.46 \pm 0.06$ \\
\hline FRic & 0.04 & 8.16 & $3.52 \pm 1.57$ & 0.04 & 8.11 & $3.54 \pm 1.48$ & 0.54 & 8.16 & $3.47 \pm 2.05$ \\
\hline FEve & 0.01 & 0.85 & $0.54 \pm 0.16$ & 0.01 & 0.85 & $0.54 \pm 0.16$ & 0.06 & 0.83 & $0.54 \pm 0.18$ \\
\hline FDiv & 0.31 & 1.00 & $0.80 \pm 0.12$ & 0.31 & 1.00 & $0.81 \pm 0.11$ & 0.40 & 0.99 & $0.78 \pm 0.13$ \\
\hline FDis & 0.06 & 1.82 & $1.12 \pm 0.36$ & 0.06 & 1.82 & $1.13 \pm 0.36$ & 0.09 & 1.78 & $1.05 \pm 0.41$ \\
\hline RaoQ & 0.05 & 3.44 & $1.60 \pm 0.69$ & 0.05 & 3.44 & $1.62 \pm 0.67$ & 0.07 & 3.27 & $1.48 \pm 0.79$ \\
\hline$A G B$ & 12.24 & 378.25 & $135.5 \pm 70.2$ & 30.38 & 378.25 & $137.8 \pm 69.6$ & 12.24 & 337.75 & $114.42 \pm 73.26$ \\
\hline
\end{tabular}


Table 3 Goodness of fit statistics for the 2nd order GLS model on taxonomic diversity, community-weighted means of trait values (CWM) and functional diversity (FD) for ABG in all permanent plots pooled together

\begin{tabular}{|c|c|c|c|c|c|c|c|c|c|c|c|}
\hline & \multicolumn{3}{|c|}{ Taxonomic diversity } & \multicolumn{3}{|l|}{ CWM } & \multicolumn{5}{|c|}{ Functional diversity (FD) } \\
\hline & $S$ & $H^{\prime}$ & $\lambda$ & Hmax & LS & WD & FDis & FDiv & FEve & FRic & RaoQ \\
\hline$\overline{r^{2}}$ & 0.05 & 0.02 & 0.01 & 0.15 & 0.01 & 0.01 & 0.05 & 0.01 & 0.01 & 0.04 & 0.06 \\
\hline$F_{1,411}$ & 11.61 & 2.56 & 1.06 & 34.79 & 0.90 & 3.38 & 11.06 & 1.75 & 0.33 & 7.12 & 12.78 \\
\hline$p$ & $<0.0001$ & 0.08 & 0.36 & $<0.0001$ & 0.41 & $<0.03$ & $<0.0001$ & 0.18 & 0.72 & $<0.0001$ & $<0.0001$ \\
\hline
\end{tabular}

related to CWM_Hmax $\left(r^{2}=0.14 ; p<0.0001\right)$, and CWM_WD $\left(r^{2}=0.02 ; p<0.03\right)$; no significant relationship between AGB and CWM_LS was observed (Table 3).

Above-ground biomass was significantly correlated with three of the five functional diversity metrics when all plots were pooled together (Table 3). The overall relationship between AGB and functional diversity was quadratic; i.e., biomass increased with functional diversity values and then decreased afterwards. In all cases AGB was highest at medium FD values.

\section{AGB in relation to diversity metrics in managed and unmanaged forest stands \\ $A G B$ in relation to taxonomic diversity}

Table 4 presents the summary of the 2nd order GLS model fitted to AGB-taxonomic diversity metrics, in both managed and unmanaged stands. Among the taxonomic diversity metrics, only species richness $(S)$ in managed stands was a significant predictor of AGB (Table 4). Figures 3, 4 and 5 show the relationship between $\mathrm{AGB}$ and taxonomic diversity obtained from

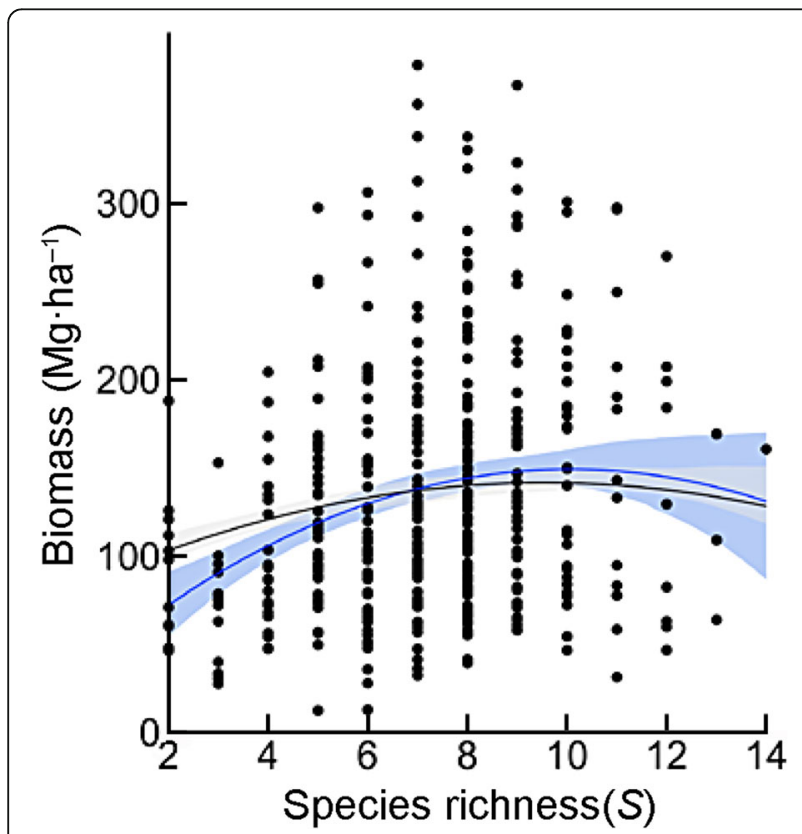

Fig. 2 AGB-species richness relationship. Blue line indicates the 2 nd order polynomial model; black line indicates the 2nd order GLS model. Shaded areas represent the $95 \%$ confidence intervals the two fitted models. The 2nd order polynomial regression model showed a unimodal relationship for AGB against species richness, Shannon-Wiener and Simpson indices in unmanaged stands; in managed stands this unimodal trend was observed only for species richness (Fig. 3). However, taking into account spatial autocorrelation the unimodal relationships disappear in all cases, except for species richness.

The highest AGB values were related to species richness values between 7 and 9; 1.5 and 0.75 to ShannonWiener and Simpson indices, respectively, in managed and unmanaged stands. The above suggests that, without considering the spatial autocorrelation, the forest management does not affect the AGB-species richness relationship in these forests.

\section{$A G B$ in relation to $C W M$ traits}

The AGB-CWM_Hmax relationship was positive and highly significant (Table 4), showing the same trend in managed and unmanaged stands (Fig. 4). With the 2nd order polynomial model, a slight negative relationship between AGB and wood density (CWM_WD) in both type of stands was observed (Fig. 4), but not with the GLS model. The above indicates that stands with hard wood species have lower productivity than stands with soft wood species. In managed and unmanaged stands the AGB-CWM_LS relationship did not show a clear trend.

\section{$A G B$ in relation to functional diversity}

Relationships between AGB and functional diversity were significant only for three indices (FDis, Fric and $\mathrm{RaQ})$ in managed stands, and for all five indices in unmanaged stands (Table 4).

All functional diversity metrics, except FDiv, showed a unimodal relationship with $\mathrm{AGB}$ in both stand types, when such relationship was described with the 2nd order polynomial model. The metrics FDis, FEve, FRic and RaoQ showed the same behavior with the GLS model. In unmanaged stands, the relationships did not show any clear trends with the GLS model (Fig. 5).

\section{Discussion}

Numerous studies have documented the relationships between biodiversity and ecosystems biomass production, 
Table 4 Goodness of fit statistics for the 2nd order GLS model on taxonomic diversity metrics, community-weighted means of trait values (CWM) and functional diversity (FD) indices for AGB in managed and unmanaged stands

\begin{tabular}{|c|c|c|c|c|c|c|c|c|c|c|c|}
\hline & \multicolumn{3}{|c|}{ Taxonomic diversity } & \multicolumn{3}{|l|}{ CWM } & \multicolumn{5}{|c|}{ Functional diversity (FD) } \\
\hline & $\bar{s}$ & $H^{\prime}$ & $\lambda$ & Hmax & LS & WD & FDis & FDiv & FEve & FRic & RaoQ \\
\hline \multicolumn{12}{|c|}{ Managed stands } \\
\hline$r^{2}$ & 0.05 & 0.01 & 0.01 & 0.13 & 0.01 & 0.01 & 0.06 & 0.01 & 0.01 & 0.08 & 0.08 \\
\hline$F_{1,362}$ & 8.68 & 0.84 & 0.23 & 25.83 & 1.01 & 1.97 & 10.91 & 1.96 & 0.12 & 13.26 & 14.22 \\
\hline$p$ & $<0.0001$ & 0.43 & 0.98 & $<0.0001$ & 0.36 & 0.14 & $<0.0001$ & 0.14 & 0.88 & $<0.0001$ & $<0.0001$ \\
\hline \multicolumn{12}{|c|}{ Unmanaged stands } \\
\hline$r^{2}$ & 0.09 & 0.04 & 0.03 & 0.48 & 0.10 & 0.10 & 0.04 & 0.01 & 0.01 & 0.04 & 0.02 \\
\hline$F_{1,46}$ & 3.31 & 9.21 & 10.03 & 20.59 & 5.63 & 2.99 & 5.98 & 4.00 & 4.95 & 3.67 & 3.75 \\
\hline$p$ & 0.05 & 0.0004 & 0.002 & $<0.0001$ & 0.006 & 0.05 & 0.004 & 0.02 & 0.01 & 0.03 & 0.03 \\
\hline
\end{tabular}

with quite different conclussions including positive, negative, hump-shaped and null relationships (Adler et al. 2011; Flynn et al. 2011; Barrufol et al. 2013; Zhang and Chen 2015). Lehman and Tilman (2000) and Barrufol et al. (2013), for instance, point out that plant diversity increases when the productivity of the community also increases, whereas Kenkel et al. (2001) found that increasing plant diversity does not influence forest biomass production. Zhang et al. (2012) performed a meta-analysis of more than 50 studies and found a monotonic increase of forest biomass with plant species diversity. In addition, Vilà et al. (2007) report a positive relationship between species richness and woody productivity across different environmental conditions in Spain. Despite this large number of studies, it

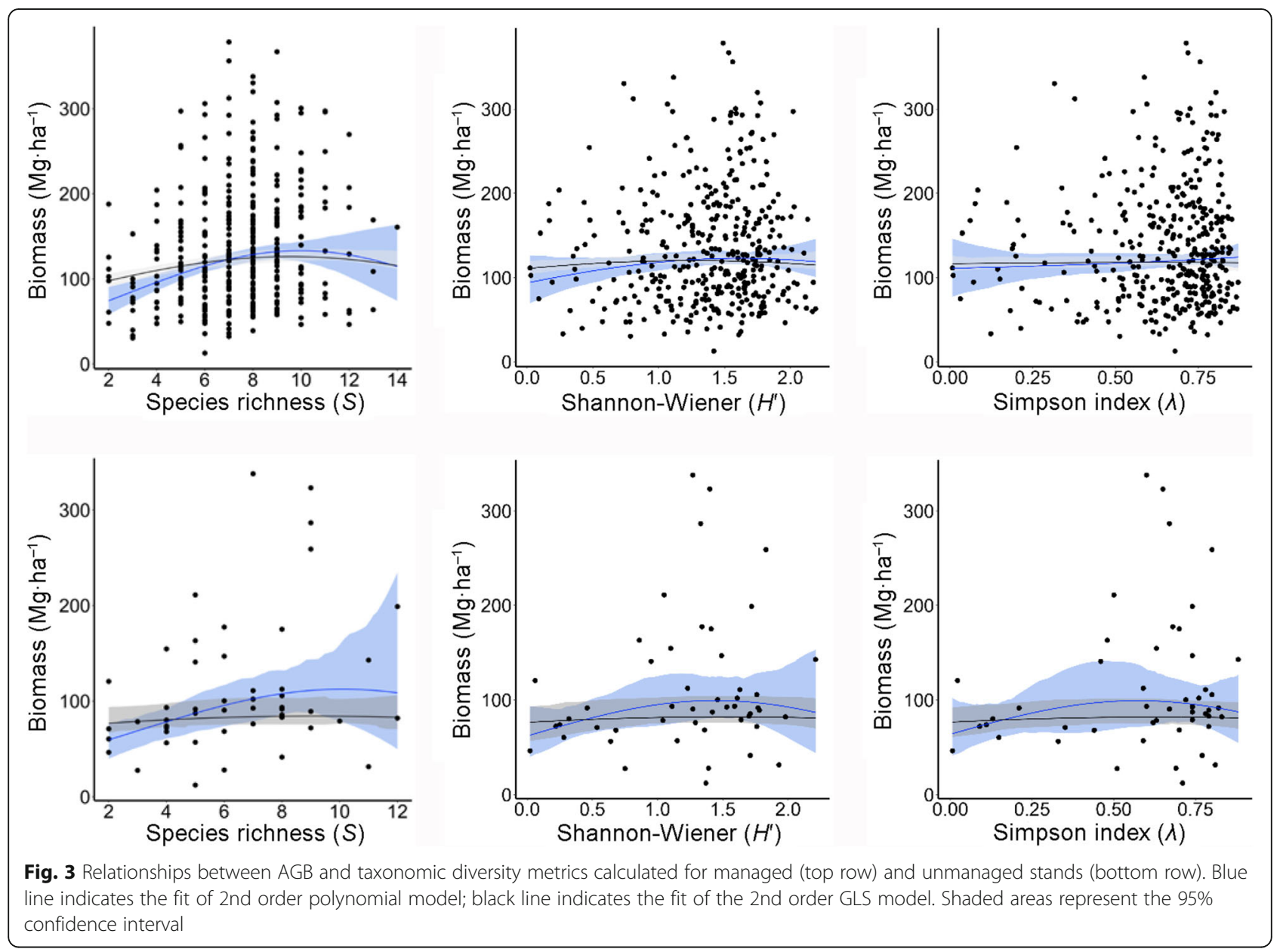



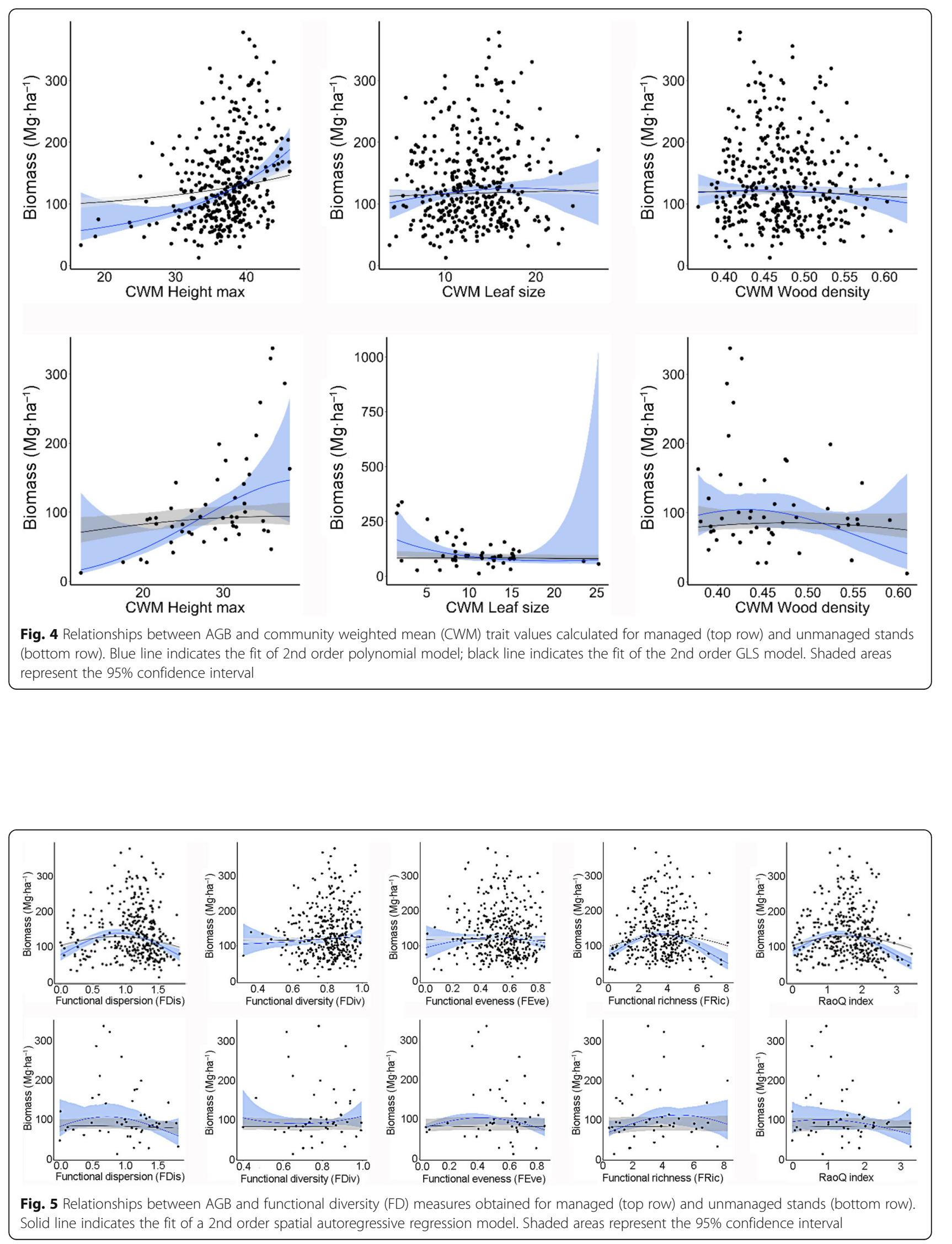
has not been possible to establish a definitive pattern that is valid for the pine-oak forests of the Sierra Madre Occidental (Corral-Rivas et al. 2019). In this study we analyze the effect of taxonomic diversity and functional diversity on above-ground biomass by employing 414 permanent plots within uneven-aged temperate forests. The results exhibited a highly variable AGB-species richness relationship, but we identified the hump-shaped (unimodal) relationship between species richness and the accumulation of total biomass (AGB), which has been frequently observed in mature ecosystems (Mittelbach et al. 2001). It is in line with the most recent global meta-analyses and empirical findings across different biomes, which reveal a consistent positive concave-down effect of biodiversity on forest productivity across the world (Liang et al. 2016). Our findings reveal that, when species richness is relatively low, AGB is also low, but increases to a certain level of species richness where the biomass is maximum; after this optimal point, AGB trends to be lower. AGB values were the highest at medium species richness values (number of species in plots between 7 and 9) and then decreased afterwards. These results are similar to those obtained by Corral-Rivas et al. (2019), who reported an optimum level of species richness between 5 and 10 species associated with the maximum volume production in temperate forests in northern Mexico. Our findings are also in line with the prevailing conclusions that the AGB-diversity is unimodal, which means that productivity peaks at intermediate levels of diversity (Adler et al. 2011; Barrufol et al. 2013; Zhang and Chen 2015; Ding et al. 2019), but are contrary to Wu et al. (2015), who found that forest biomass in temperate forest in China was positively related $\left(R^{2}=0.08\right)$ with especies richness; Ammer (2019), who pointed out that, although it is difficult to generalize a definitive pattern, the shape of the curve relating forest productivity to tree species diversity represents an asymptotic curve, and that it seems to be similar across biomes (Liang et al. 2016).

Adler et al. (2011) mentioned that the theoretical basis for a hump-shaped stand productivity-species richness relationship has been challenged, and that methodological differences confound cross-study comparisons of empirical evidences (Gotelli and Colwell 2001). We present empirical evidence that the classical hump-shaped productivity (measured as AGB)species richness may be found in the temperate mixed-species and uneven-aged forests of the Sierra Madre Occidental in Mexico.

The highest biomass level was found close to 380 $\mathrm{Mg} \cdot \mathrm{ha}^{-1}$ for the three taxonomic diversity metrics used, and it is related to 7, 0.9 and 2.1 values of species richness $(S)$, Shannon-Wiener $\left(H^{\prime}\right)$ and Simpson $(\lambda)$ indices, respectively (Fig. 2). The mechanisms behind these relationships have been discussed in terms of species facilitation and competition. When biomass is relatively low, species richness increases due to interspecific facilitation (Guo 2007); whereas when biomass accumulates to a certain point, competition leads to lower diversity (Weiner and Thomas 2001). This pattern could be consequence of the interspecific interactions at community level, where niche differentiation and facilitative interactions between species improve the utilization of available limiting resources (Wang et al. 2016). In this study, when species richness increased, AGB accumulation had a peak, and then reached a decline. Interestingly, AGB peak corresponded with the average values of species richness, Shanon-Wiener and Simpson indices (Table 2, Fig. 2). These results are consistent with Wang et al. (2016), who state that, when species diversity reaches a certain degree, the productivity may also peak at intermediate diversity leves due to saturation in resource utilization.

Nevertheless, it is important to point out that this relationship could be influenced by others factors besides diversity, such as environmental variables, whose effects on productivity and species richness change along altitudinal gradients (Wu et al. 2015). In this sense, in additional analysis we observed a unimodal relationship between AGB and altitude $\left(r^{2}=0.02 ; F_{2,411}=3.31 ; p<\right.$ $0.03)$, a negative trend between $\mathrm{AGB}$ and temperature $\left(r^{2}=0.04 ; F_{2,411}=8.81 ; p \leq 0.0001\right)$, while the relationship between AGB and precipitation was positive $\left(r^{2}=0.21\right.$; $\left.F_{2,411}=47.61 ; p<0.0001\right)$. Because these relationships were not objective of this study, future research should include the impact assess of climatic variables on $A G B$ to confirm these observations.

We compare our results with some studies that reported positive or hump-shaped AGB-diversity relationships in terms of correlation degree. We found that the effects of species richness on AGB production yield up $10 \%$ across the temperate pine-oak northern Mexico (Table 4), which is greater than $6 \%$ reported by $\mathrm{Wu}$ et al. (2015) for boreal and temperate forest across China. For similar forest ecosystems to the one considered in this study, low $R^{2}$ values have been reported; for example, Cavanaugh et al. (2014), Potter and Woodall (2014), and Wardle et al. (2006), who reported 0.16, $0.00-0.25$, and 0.21 , respectively. Wu et al. (2015) states that the $R^{2}$ values between diversity and biomass reported are generally less than 0.3 , and that more than $70 \%$ of variation in forest biomass can not be explained by biodiversity, which coincides with the results obtained in this study.

The above discussed confirms that the AGB-species richness relationship is highly complex ( $\mathrm{Li}$ et al. 2018), and it is because Adler et al. (2011) highlights that productivity is a poor predictor of plant species richness. Such a conclusive statement has led to the use of species-level functional traits or functional-trait based 
approaches to better link biodiversity with forest productivity.

We evaluated the effect of forest management on diversity and AGB production, contrasting managed and unmanaged stands. We were unable to find a clear influence of management on species richness, CWM traits, or functional diversity values, because minimum and maximum values of species richness, as well as all other taxonomic diversity and functional diversity measures used were similar in both managed and unmanaged stands. These findings extend those of Duguid and Ashton (2013), confirming that there is no clear influence of forest management on overstory plant biodiversity when contrasting managed and unmanaged stands. Our results are opposite to the findings by Paillet et al. (2010), who carried out a study to evaluate biodiversity differences between managed and unmanaged forests in Europe, that species richness was only marginally higher in unmanaged than in managed forests, which means that the effect of management on biodiversity is not clearly identificable.

We attribute the heigher AGB and species richness in managed stands, to harvesting regimes. Selective felling is the dominant management type in the Sierra Madre Occidental; it is a management method that prescribes harvest of selected trees within a planning horizon defined by the cutting cycle (ranging up 70 years). A dominant characteristic of this method is the regulation of harvesting regimes to guarantee the natural state and ecological diversity of the forests (Torres-Rojo et al. 2016). This type of management (known as close-tonature-silviculture) has maintained a diverse structure with small, medium and large trees in a multi-layered canopy, and it has originated uneven-aged multispecies stands. That is compelling evidence that current forest management does not negatively affects the AGBdiversity relationships in these forests.

In the last two decades, there has been a growing consensus regarding the importance of using functional traits as predictors of forest productivity measured through biomass (Díaz and Cabido 2001). Furthermore, it has been widely observed that patterns in functional traits can be used to predict relationships in species communities, because they represent the evolutionary processes of species; and the mean values of the traits at the community level are interpreted as results of the niche complementarity or the mass ratio (CavenderBares et al. 2009; Götzenberger et al. 2012; HilleRisLambers et al. 2012). In this sense, this study used functional diversity metrics, as well as the community weighted means $(\mathrm{CWM})$ of three functional traits as drivers of the AGB in managed and unmanaged forest stands. CWM traits better correlated with AGB (Table 4) than did taxonomic diversity or FD metrics, in both managed and unmanaged stands, indicating, as Roscher et al. (2012) highlight, that the temperate forests evaluated containing dominant species with different trait combinations reached high productivity. Our analyses showed that AGB was best explained by CWM_Hmax, which indicates that dominant height is the most important trait for high productivity. This has sense, because the dominant height attained by a forest stand at a specified age (known as site index), is the most widely used indicator of potential productivity in forest ecosystems (Hägglund 1981; Vanclay 1994).

Our results suggest that the mass-ratio and environmental filtering hypotheses are not mutually exclusive (Table 3). However, the mass-ratio hypothesis explains to a greater extent the relationship between biomass and functional diversity, since it postulates that the production rate of an ecosystem process, e.g. AGB, is mainly determined by a set of dominant species (Grime 1988). Therefore, under the assumptions of the hypothesis, that is, considering that the environment is uniform, the woody species community has the highest biomass production by a set of species with dominant traits (Pinus cooperi, $P$. durangensis, $P$. arizonica, Quercus sideroxyla, and Cupressus lusitanica in unmanaged stands; Pinus durangensis, Quercus sideroxyla, P. arizonica, P. herreae, and $P$. cooperi in manage stands) which, in our study, represent $63 \%$ and $65 \%$ of the total AGB, respectively.

Furthermore, the null relationship between AGB and functional evenness (FEve) confirms the low contribution of environmental filtering and the facilitating processes in biomass production. Studies carried out by Vile et al. (2006), and Sonkoly et al. (2019) in grass ecosystems in France and Hungary, respectively, as well as studies carried out in tropical ecosystems in Brazil (Duarte et al. 2010) and Costa Rica (Finegan et al. 2015) and temperate forests in China (Yuan et al. 2018) found similar patterns regarding the mechanisms that influence biomass.

On the other hand, our results suggest that forest management is favoring the permanence and abundance of species with commercial importance. The relationship between forest management and the increase in stand biomass as a consequence of the reduction in intra and interspecific competition has been widely documented (Binkley 2004; Juodvalkis et al. 2005). For example, Pretzsch (2005) found that reducing the basal area of beech stands may, to some extent, increase productivity. However, favoring the establishment of a set of high commercial value species may be reducing functional features, functional diversity, and consequently the mechanisms of environmental filtering. Consequently, the null relationship between biomass and functional diversity metrics could be being masked by forest management. 
Finally, we must highlight the importance of taking into account the spatial autocorrelation of biomass between plots (Dormann et al. 2007; Fortin and Dale 2009). As shown in Figs. 3, 4 and 5, the inclusion of spatial autocorrelation reduced the effect of the explanatory variables on AGB, even leading to the elimination of the effect, highlighting the existence of spurious relationships. Additionally, it is observed that the incorporation of the spatial autocorrelation reduces the uncertainty on the relationships, i.e., smaller confidence intervals.

\section{Conclusions}

Species richness does not influence biomass production in the temperate mixed-species and uneven-aged forests of northern Mexico. These forests show the classic hump-shaped AGB-species richness relationship, with biomass accumulation increasing at low to intermediate levels of species plant diversity and decreasing at high species richness. Functional diversity explains better AGB production than classical taxonomic diversity metrics. Multi-trait functional diversity, but not classical taxonomic diversity, provides key information to explain stand biomass in these forests, where the single trait maximum tree height seems to be the the better option for understanding the biomass accumulation process in these ecosystems. Altohugh the impact of forest management on biodiversity is still debated, it has not changed the AGB-diversity relationships in the forests of the Sierra Madre Occidental, Mexico.

\section{Authors' contributions}

$B V L$ and JOLM designed the idea, performed analysis, and wrote the manuscript paper; EGL performed the statistical analysis, JCR collected data, JCR and JFH review the manuscript. All authors reviewed and authorized the manuscript.

\section{Availability of data and materials}

The datasets used and/or analysed during the current study are available from the corresponding author on reasonable request.

Ethics approval and consent to participate

Not applicable.

\section{Consent for publication}

Not applicable.

\section{Competing interests}

The authors declare that they have no competing interests.

\section{Author details}

${ }^{1}$ Tecnológico Nacional de México/Instituto Tecnológico de El Salto, 34942 El Salto, Durango, Mexico. ${ }^{2}$ Cátedras, CONACYT, 1582, Av. Insurgentes Sur, Ciudad de México, Mexico. ${ }^{3}$ El Colegio de la Frontera Sur, 77014, Chetumal, Quintana Roo, Mexico. ${ }^{4}$ Departamento de Ecología y Recursos Naturales, Facultad de Ciencias, Universidad Nacional Autónoma de México, Ciudad de México, Mexico. ${ }^{5}$ Facultad de Ciencias Forestales, Universidad Juárez del Estado de Durango, Río Papaloapan y Blvd. Durango s/n, Col. Valle del Sur, 34120 Durango, Mexico.
Received: 22 July 2020 Accepted: 12 January 2021

Published online: 31 January 2021

\section{References}

Adler PB, Seabloom EW, Borer ET, Hillebrand H, Hautier Y, Hector A, Harpole WS, O'Halloran LR, Grace JB, Anderson TM, Bakker JD, Biederman LA, Brown CS, Buckley YM, Calabrese LB, Chu CJ, Cleland EE, Collins SL, Cottingham KL, Crawley MJ, Damschen El, Davies KF, DeCrappeo NM, Fay PA, Firn J, Frater P, Gasarch El, Gruner DS, Hagenah N, Hille Ris Lambers J, Humphries H, Jin VL, Kay AD, Kirkman KP, Klein JA, Knops JMH, La Pierre KJ, Lambrinos JG, Li W, MacDougall AS, McCulley RL, Melbourne BA, Mitchell CE, Moore JL, Morgan JW, Mortensen B, Orrock JL, Prober SM, Pyke DA, Risch AC, Schuetz M, Smith MD, Stevens CJ, Sullivan LL, Wang G, Wragg PD, Wright JP, Yang LH (2011) Productivity is a poor predictor of plant species richness. Science 333:1750-1753 Ammer C (2019) Diversity and forest productivity in a changing climate. New Phytol 221:50-66

Barrufol M, Schmid B, Bruelheide H, Chi X, Hector A, Ma K, Michalski S, Tang Z, Niklaus PA (2013) Biodiversity promotes tree growth during succession in subtropical forest. PLoS One 8:e81246

Becknell JM, Powers JS (2014) Stand age and soils as drivers of plant functional traits and aboveground biomass in secondary tropical dry forest. Can J For Res 44:604-613

Binkley D (2004) A hypothesis about the interaction of tree dominance and stand production through stand development. For Ecol Manag 190:265-271

Cavanaugh KC, Gosnell JS, Davis SL, Ahumada J, Boundja P, Clark DB, Mugerwa B, Jansen PA, O'Brien TG, Rovero F, Sheil D, Vasquez R, Andelman S (2014) Carbon storage in tropical forests correlates with taxonomic diversity and functional dominance on a global scale: biodiversity and aboveground carbon storage. Glob Ecol Biogeogr 23:563-573

Cavender-Bares J, Kozak KH, Fine PVA, Kembel SW (2009) The merging of community ecology and phylogenetic biology. Ecol Lett 12:693-715

Challenger A (1998) Utilización y conservación de los ecosistemas terrestres de México: pasado presente y futuro. CONABIO, IUCN

Chao A, Gotelli NJ, Hsieh TC, Sanders EL, Ma KH, Colwell RK, Ellison AM (2014) Rarefaction and extrapolation with Hill numbers: a framework for sampling and estimation in species diversity studies. Ecol Monogr 84:45-67

Cheng Y, Zhang C, Zhao X, von Gadow K (2018) Biomass-dominant species shape the productivity-diversity relationship in two temperate forests. Ann For Sci 75:97

Cianciaruso MV, Batalha MA, Gaston KJ, Petchey OL (2009) Including intraspecific variability in functional diversity. Ecology 90:81-89

Colwell RK, Chao A, Gotelli NJ, Lin S-Y, Mao CX, Chazdon RL, Longino JT (2012) Models and estimators linking individual-based and sample-based rarefaction, extrapolation and comparison of assemblages. J Plant Ecol 5:3-21

Conti G, Díaz S (2013) Plant functional diversity and carbon storage - an empirical test in semi-arid forest ecosystems. J Ecol 101(1):18-28

Cornelissen JHC, Lavorel S, Garnier E, Díaz S, Buchmann N, Gurvich DE, Reich PB, ter Steege H, Morgan HD, van der Heijden MGA, Pausas JG, Poorter H (2003) A handbook of protocols for standardised and easy measurement of plant functional traits worldwide. Aust J Bot 51:335-380

Cornwell WK, Schwilk LDW, Ackerly DD (2006) A trait-based test for habitat filtering: convex hull volume. Ecology 87:1465-1471

Corral-Rivas JJ, González-Elizondo MS, Lujan-Soto JE, von Gadow K (2019) Effects of density and structure on production in the communal forests of the Mexican Sierra Madre Occidental. South For 81:1-10

Crecente-Campo F, Corral-Rivas JJ, Vargas-Larreta B, Wehenkel C (2014) Can random components explain differences in the height-diameter relationship in mixed uneven-aged stands? Ann For Sci 71:51-70

Díaz S, Cabido M (2001) Vive la différence: plant functional diversity matters to ecosystem processes. Trends Ecol Evol 16:646-655

Díaz S, Lavorel S, de Bello F, Quétier F, Grigulis K, Robson TM (2007) Incorporating plant functional diversity effects in ecosystem service assessments. Proc Natl Acad Sci U S A 104:20684-20689

Ding Y, Zang R, Lu X, Huang J, Xu Y (2019) The effect of environmental filtering on variation in functional diversity along a tropical elevational gradient. J Veg Sci 30:973-983

Dormann CF, McPherson JM, Araújo MB, Bivand R, Bolliger J, Carl G, Davies RG, Hirzel A, Jetz W, Kissling WD, Kühn I, Ohlemüller R, Peres-Neto PR, Reineking B, Schröder B, Schurr M, Wilson R (2007) Methods to account for spatial autocorrelation in the analysis of species distributional data: a review. Ecography 30(5):609-628 
Duarte LS, Hofmann GS, Dos Santos MMG, Hartz SM, Pillar VD (2010) Testing for the influence of niche and neutral factors on sapling community assembly beneath isolated woody plants in grasslands. J Veg Sci 21:462-471

Duguid MC, Ashton MS (2013) A meta-analysis of the effect of forest management for timber on understory plant species diversity in temperate forests. For Ecol Manag 303:81-90

Farjon A, Filer D (2013) An atlas of the World's conifers: an analysis of their distribution, biogeography, diversity and conservation status. Brill

Finegan B, Peña-Claros M, de Oliveira A, Ascarrunz N, Bret-Harte MS, CarreñoRocabado G, Casanoves F, Díaz S, Eguiguren-Velepucha P, Fernandez F, Licona JC, Lorenzo L, Salgado-Negret B, Vaz M, Poorter L (2015) Does functional trait diversity predict above-ground biomass and productivity of tropical forests? Testing three alternative hypotheses. J Ecol 103:191-201

Flynn DFB, Mirotchnick N, Jain M, Palmer MI, Naeem S (2011) Functional and phylogenetic diversity as predictors of biodiversity-ecosystem-function relationships. Ecology 92:1573-1581

Forrester DI, Bauhus J (2016) A Review of Processes Behind Diversity_Productivity Relationships in Forests. Current Forestry Reports 2:45-61

Fortin M-J, Dale MRT (2009) Spatial autocorrelation in ecological studies: A legacy of solutions and myths: Spatial autocorrelation in ecological studies. Geogr Anal 41:392-397

Gamfeldt L, Snäll T, Bagchi R, Jonsson M, Gustafsson L, Kjellander P, Ruiz-Jaen MC, Fröberg J, Philipson CD, Mikusińsky Andersson E, Westerlund B, Andrén H, Morberg F, Moen J, Bengtsson J (2013) Higher levels of multiple ecosystem services are found in forests with more tree species. Nat Commun 4:1340

García AA, González MS (2003) Pináceas de Durango. Instituto de Ecología AC Comisión Nacional Forestal México

Garnier E, Cortez J, Billès G, Navas ML, Roumet C, Debussche M, Laurent G, Blanchard A, Aubry D, Bellmann A, Neill C, Toussaint JP (2004) Plant functional markers capture ecosystem properties during secondary succession. Ecology 85:2630-2637

González-Elizondo MS, González-Elizondo M, Tena-Flores JA, Ruacho-González L, López-Enríquez IL (2012) Vegetación de la sierra madre occidental, México: Una síntesis. Acta Bot Mex:351-403

Gotelli NJ, Colwell RK (2001) Quantifying biodiversity: procedures and pitfalls in the measurement and comparison of species richness. Ecol Lett 4:379-391

Götzenberger L, de Bello F, Bråthen KA, Davison J, Dubuis A, Guisan A, Lepš J, Lindborg R, Moora M, Pärtel M, Pellissier L, Pottier J, Vittoz P, Zobel K, Zobel M (2012) Ecological assembly rules in plant communities-approaches, patterns and prospects. Biol Rev Camb Philos Soc 87:111-127

Grace JB, Anderson TM, Seabloom EW, Borer ET, Adler PB, Harpole WS, Hautier Y, Hillebrand H, Lind EM, Pärtel M, Bakker JD, Buckley YM, Crawley MJ, Damschen El, Davies KF, Fay PA, Firn J, Gruner DS, Hector A, Knops JMH, MacDougall AS, Melbourne B, Morgan JW, Orrock J, Prober S, Smith MD (2016) Integrative modelling reveals mechanisms linking productivity and plant species richness. Nature 529:390-393

Grime JP (1988) The CSR model of primary plant strategies-origins, implications and tests. In: Plant evolutionary biology. Springer, Dordrecht

Guo Q (2007) The diversity-biomass-productivity relationships in grassland management and restoration. Basic Appl Ecol 8:199-208

Hagglund B (1981) Evaluation of forest site productivity

HilleRisLambers J, Adler PB, Harpole WS, Levine JM, Mayfield MM (2012) Rethinking community assembly through the lens of coexistence theory. Ann Rev Ecol Evol Syst 43:227-248

Hooper DU, Chapin FS III, Ewel JJ, Hector A, Inchausti P, Lavorel S, Lawton JH, Lodge DM, Loreau M, Naeem S, Schmid B, Setälä H, Symstad AJ, Vandermeer J, Wardle DA (2005) Effects of biodiversity on ecosystems functioning: a consensus of current knowledge. Ecol Monogr 75:3-35

Hsieh TC, Ma KH, Chao A (2016) iNEXT: an R package for rarefaction and extrapolation of species diversity (Hill numbers). Methods Ecol Evol 7:1451-1456

Isbell F, Tilman D, Polasky S, Loreau M (2015) The biodiversity-dependent ecosystem service debt. Ecol Lett 18:119-134

Juodvalkis A, Kairiukstis L, Vasiliauskas R (2005) Effects of thinning on growth of six tree species in north-temperate forests of Lithuania. Eur J For Res 124: 187-192

Kenkel NC, Peltzer DA, Baluta D, Pirie D (2001) Increasing plant diversity does not influence productivity: empirical evidence and potential mechanisms. Community Ecol 1:165-170

Kirby KR, Potvin C (2007) Variation in carbon storage among tree species: implications for the management of a small-scale carbon sink project. For Ecol Manag 246(2-3):208-221
Laliberté E, Legendre P (2010) A distance-based framework for measuring functional diversity from multiple traits. Ecology 91:299-305

Lawton JH, Brown VK (1994) Redundancy in ecosystems. Biodiversity and ecosystem function. Ecology 85:1534-1540

Lehman CL, Tilman D (2000) Biodiversity, stability, and productivity in competitive communities. Am Nat 156:534-552

Leps J, de Bello F, Lavorel S, Berman S (2006) Quantifying and interpreting functional diversity of natural communities: practical considerations matter. Preslia 78:481-501

Li S, Lang X, Liu W, Ou G, Xu H, Su J (2018) The relationship between species richness and aboveground biomass in a primary Pinus kesiya forest of Yunnan, southwestern China. PLoS One 13:e0191140

Liang J, Crowther TW, Picard N, Wiser S, Zhou M, Alberti G, Schulze ED, McGuire $A D$, Bozzato $F$, Pretzsch $H$, de-Miguel $S$, Paquette $A$, Hérault $B$, SchererLorenzen M, Barrett CB, Glick HB, Hengeveld GM, Nabuurs GJ, Pfautsch S, Viana $H$, Vibrans AC, Ammer C, Schall P, Verbyla D, Tchebakova N, Fischer M, Watson JV, HYH C, Lei X, Schelhaas MJ, Lu H, Gianelle D, Parfenova El, Salas C, Lee E, Lee B, Kim HS, Bruelheide H, Coomes DA, Piotto D, Sunderland T, Schmid B, Gourlet-Fleury S, Sonké B, Tavani R, Zhu J, Brandl S, Vayreda J, Kitahara F, Searle EB, Neldner VJ, Ngugi MR, Baraloto C, Frizzera L, Bałazy R, Oleksyn J, Zawiła-Niedźwiecki T, Bouriaud $O$, Bussotti F, Finér $L$, Jaroszewicz $B$, Jucker $T$, Valladares $F$, Jagodzinski AM, Peri PL, Gonmadje C, Marthy W, O'Brien T, Martin EH, Marshall AR, Rovero F, Bitariho R, Niklaus PA, Alvarez-Loayza P, Chamuya N, Valencia R, Mortier F, Wortel V, Engone-Obiang NL, Ferreira LV, Odeke DE, Vasquez RM, Lewis SL, Reich PB (2016) Positive biodiversity-productivity relationship predominant in global forests. Science 354(6309):aaf8957

Madrid L, Núñez JM, Quiroz G, Rodríguez Y (2009) La propiedad forestal social en México. Investigaciones Ambientales 1:179-196

Mason NWH, MacGillivray K, Steel JB, Wilson JB (2003) An index of functional diversity. J Veg Sci 14:571-578

Mason NWH, Mouillot D, Lee WG, Wilson JB (2005) Functional richness, functional evenness and functional divergence: the primary components of functional diversity. Oikos 111:112-118

McGill BJ, Maurer BA, Weiser MD (2006) Empirical evaluation of neutral theory. Ecology 87:1411-1423

Mittelbach GG, Steiner CF, Scheiner SM, Gross KL, Reynolds HL, Waide RB, Willig MR, Dodson SI, Gough L (2001) What is the observed relationship between productivity and species richness. Ecology 82:2381-2396

Ordoñez Díaz JAB, Galicia Naranjo A, Venegas-Mancera NJ, Hernández-Tejeda T, Ordoñez-Díaz MJ, Davalos-Sotelo R (2015) Density of Mexican woods by vegetation type based on J. Rzedowski's classification: compilation. Madera Bosques 21:77-126

Padilla-Martínez JR, Corral-Rivas JJ, Briseño-Reyes J, Paul C, López-Serrano PM, v. Gadow K, (2020) Patterns of Density and Production in the Community Forests of the Sierra Madre Occidental, Mexico. Trees Livelihoods 11:307

Paillet $Y$, Bergès L, Hjältén J, Ódor P, Avon C, Bernhardt-Römermann M, Bijlsma RJ, De Bruyn LUC, Fuhr M, Grandin ULF et al (2010) Biodiversity differences between managed and unmanaged forests: meta-analysis of species richness in Europe. Conserv Biol 24:101-112

Pérez-Harguindeguy N, Díaz S, Garnier E, Lavorel S, Poorter H, Jaureguiberry P, Bret-Harte MS, Cornwell WK, Craine JM, Gurvich DE, Urcelay C, Veneklaas EJ, Reich PB, Poorter L, Wright IJ, Ray P, Enrico L, Pausas LG, Buchmann AC, Funes G, Quétier F, Hodgson JG, Thompson K, Morgan HD, ter Steege H, van der Heijden MGA, Sack L, Blonder B, Poschlod P, Vaieretti MV, Conti G, Staver AC, Aquino S, Cornelissen JHC (2013) New handbook for standardized measurement of plant functional traits worldwide. Aust J Bot 61:167-234

Petchey OL, Gaston KJ (2002) Functional diversity (FD), species richness and community composition. Ecol Lett 5:402-411

Petchey OL, O'Gorman EJ, Flynn DFB (2009) A functional guide to functional diversity measures. In: Naeem S, Bunker DE, Hector A, Loreau M, Perrings C (eds) Biodiversity, ecosystem functioning, and human wellbeing. Oxford University Press, Oxford

Pinheiro J, Bates D, DebRoy S, Sarkar D, R Core Team (2020) nlme: linear and nonlinear mixed effects models. R package version 3, pp 1-149 https://CRAN. R-project.org/package $=n / m e>$. Accessed 26 Oct 2020

Poorter L, Wright SJ, Paz H, Ackerly DD, Condit R, Ibarra-Manríquez G, Harms KE, Licona JC, Martínez-Ramos M, Mazer SJ, Muller-Landau HC, PeñaClaros M, Webb CO, Wright IJ (2008) Are functional traits good predictors of demographic rates? Evidence from five neotropical forests. Ecology 89:1908-1920 
Potter KM, Woodall CW (2014) Does biodiversity make a difference? Relationships between species richness, evolutionary diversity, and aboveground live tree biomass across U.S. forests. For Ecol Manag 321:117-129

Pretzsch H (2005) Stand density and growth of Norway spruce (Picea abies (L.) Karst.) and European beech (Fagus sylvatica L.): evidence from long-term experimental plots. Eur J For Res 124:193-205

R Core Team (2020) R: a language and environment for statistical computing. $R$ Foundation for Statistical Computing, Vienna https://www.R-project.org/. Accessed 26 Oct 2020

Rao CR (1982) Diversity and dissimilarity coefficients: A unified approach. Theor Popul Biol 21:24-43

Reich PB, Tilman D, Naeem S, Ellsworth DS, Knops J, Craine J, Wedin D, Trost J (2004) Species and functional group diversity independently influence biomass accumulation and its response to $\mathrm{CO} 2$ and N. Proc Natl Acad Sci U S A 101:10101-10106

Rojas-García F, De Jong BHJ, Martínez-Zurimendí P, Paz-Pellat F (2015) Database of 478 allometric equations to estimate biomass for Mexican trees and forests. Ann For Sci 72:835-864

Roscher C, Schumacher J, Gubsch M, Lipowsky A, Weigelt A, Buchmann N, Schmid B, Schulze ED (2012) Using plant functional traits to explain diversityproductivity relationships. PLoS One 7:e36760

Rüger N, Wirth C, Wright SJ, Condit R (2012) Functional traits explain light and size response of growth rates in tropical tree species. Ecology 93:2626-2636

Ruiz-Benito P, Gómez-Aparicio L, Paquette A, Messier C, Kattge J, Zavala MA (2014) Diversity increases carbon storage and tree productivity in Spanish forests. Glob Ecol Biogeogr 23:311-322

Schuldt A, Assmann T, Bruelheide H, Durka W, Eichenberg D, Härdtle W, Kröber W, Michalski SG, Purschke O (2014) Functional and phylogenetic diversity of woody plants drive herbivory in a highly diverse forest. New Phytol 202:864-873

Schumacher J, Roscher C (2009) Differential effects of functional traits on aboveground biomass in semi-natural grasslands. Oikos 118(11):1659-1668

Silva-Flores R, Pérez-Verdín G, Wehenkel C (2014) Patterns of tree species diversity in relation to climatic factors on the Sierra Madre Occidental, Mexico. PLoS One 9:e105034

Smith TE (2020) Notebook for spatial data analysis. [online] http://www.seas. upenn.edu/ ese502/\#notebook

Sonkoly J, Kelemen A, Valkó O, Deák B, Kiss R, Tóth K, Miglécz T, Tóthmérész B, Török P (2019) Both mass ratio effects and community diversity drive biomass production in a grassland experiment. Sci Rep 9:1848

Tilman D (1997) Community invasibility, recruitment limitation, and grassland biodiversity. Ecology 78:81-92

Tilman D (2001) Functional diversity. In: Encyclopedia of biodiversity. https://doi. org/10.1016/b0-12-226865-2/00132-2 Accessed 26 Oct 2020

Tilman D, Knops J, Wedin D, Reich P, Ritchie M, Siemann E (1997) The influence of functional diversity and composition on ecosystem processes. Science 277:1300-1302

Torres-Rojo JM, Magaña-Torres OS, Moreno-Sánchez F (2016) Predicción del cambio de uso/cobertura arbolada en México a través de probabilidades de transición. Agrociencia 50:769-785

Vanclay JK (1994) Modelling forest growth and yield: applications to mixed tropical forest. CAB International, Wallingford

Vargas-Larreta B, López-Sánchez CA, Corral-Rivas JJ, López-Martínez JO, AguirreCalderón CG, Álvarez-González JG (2017) Allometric equations for estimating biomass and carbon stocks in the temperate forests of North-Western Mexico. Forests 8:269

Vilà M, Vayreda J, Comas L, Ibáñez JJ, Mata T, Obón B (2007) Species richness and wood production: a positive association in Mediterranean forests. Ecol Lett 10:241-250

Vile D, Shipley B, Garnier E (2006) Ecosystem productivity can be predicted from potential relative growth rate and species abundance. Ecol Lett 9:1061-1067

Villéger S, Mason NWH, Mouillot D (2008) New multidimensional functional diversity indices for a multifaceted framework in functional ecology. Ecology 89:2290-2301

Violle C, Navas ML, Vile D, Kazakou E, Fortunel C, Hummel I, Garnier E (2007) Let the concept of trait be functional! Oikos 116:882-892

Vitousek PM, Hooper DU (1993) Biological diversity and terrestrial ecosystem biogeochemistry. In: Schulze ED, Mooney HA (eds) Biodiversity and ecosystem function. Springer, Berlin, pp 3-14
Wang Z, Luo T, Li R, Tang Y, Du M (2012) Causes for the unimodal patterns of biomass and productivity in alpine grasslands along a large altitudinal gradient in semi-arid regions. J Veg Sci 24:198-201

Wang J, Cheng Y, Zhang C, Zhao Y, Zhao X, Von Gadow K (2016) Relationships between tree biomass productivity and local species diversity. Ecosphere 7 : 74

Wardle DA, Yeates GW, Barker GM, Bonner KI (2006) The influence of plant litter diversity on decomposer abundance and diversity. Soil Biol Biochem 38: 1052-1062

Weiner J, Thomas SC (2001) The nature of tree growth and the "age-related decline in forest productivity". Oikos 94:374-376

Wright SJ, Kitajima K, Kraft NJB, Reich PB, Wright IJ, Bunker DE, Condit R, Dalling JW, Davies SJ, Díaz S, Engelbrecht BMJ, Harms KE, Hubbell SP, Marks CO, Ruiz-Jaen MC, Salvador CM, Zanne AE (2010) Functional traits and the growth-mortality trade-off in tropical trees. Ecology 91:3664-3674

Wu X, Wang X, Wu Y, Xia X, Fang J (2015) Forest biomass is strongly shaped by forest height across boreal to tropical forests in China. J Plant Ecol 8:559-567

Yuan Z, Ali A, Wang S, Gazol A, Freckleton R, Wang X, Lin F, Ye J, Zhou L, Hao Z, Loreau M (2018) Abiotic and biotic determinants of coarse woody productivity in temperate mixed forests. Sci Total Environ 630:422-431

Zhang Y, Chen HYH (2015) Individual size inequality links forest diversity and above-ground biomass. J Ecol 103:1245-1252

Zhang Y, Chen HYH, Reich PB (2012) Forest productivity increases with evenness, species richness and trait variation: a global meta-analysis: diversity and productivity relationships. J Ecol 100:742-749

\section{Submit your manuscript to a SpringerOpen ${ }^{\odot}$ journal and benefit from:}

- Convenient online submission

- Rigorous peer review

- Open access: articles freely available online

- High visibility within the field

- Retaining the copyright to your article

Submit your next manuscript at $\boldsymbol{\nabla}$ springeropen.com 